\title{
SPEARFISHING IN THE CANARY ISLANDS: IS THE DEVIL AS BLACK AS IT SEEMS TO BE?
}

\author{
Pablo Martín-Sosa* \\ Spanish Institute of Oceanography
}

\begin{abstract}
Spearfishing is traditionally recognized as catching spawners of species with a top trophic position that are slow-growing and highly vulnerable. This study is the first empirical research in The Canary Islands quantifying this activity's pressure and impact with real catch information. The mean fishing effort by fisher is 6 days per annum at sea, with a mean yield of $390 \mathrm{~g} /$ fisher*hour. These figures outcome an estimate of 39700 total days per annum at sea and a total annual catch $(41.7 \mathrm{t})$ being $0.28 \%$ of professional sector landings. Average trophic level and Intrinsic Vulnerability Index in the catch are 3.24 and 45.72 respectively. Sparisoma cretense, a fast growing fish, with a mid trophic level and not such a vulnerable species, is at the top of spearfishing catches. The sector is described socioeconomically by questionnaires $(n=179)$. Results represent a baseline and foundation for the sector management. No evidence has been found to justify the current spatially restricted access of spearfishing to resources.
\end{abstract}

KEYwORDs: Recreational fisheries, fisheries management, infralittoral ecosystems, intrinsic vulnerability, trophic level, Sparisoma cretense.

\section{PESCA SUBMARINA EN LAS ISLAS CANARIAS: ¿ES EL LEÓN TAN FIERO COMO LO PINTAN?}

\section{RESUMEN}

La pesca submarina es conocida por capturar grandes reproductores, con una alta posición trófica, de lento crecimiento y altamente vulnerables. Este estudio es la primera investigación empírica en las islas Canarias que trata de cuantificar las presiones e impactos de esta actividad utilizando información de capturas reales. La media de esfuerzo pesquero por pescador es de 6 días al año en el mar, con una media de captura de 390 g/pescador *hora. Esto resulta en una estima de 39700 días de pesca al ańo en el mar y una captura anual total de 41.7 t, siendo $0.28 \%$ de las descargas del sector profesional. El nivel trófico medio y el índice de vulnerabilidad intrínseca es de 3,24 y 45,72 respectivamente. Sparisoma cretense, un pez de crecimiento rápido, con un nivel trófico medio y poco vulnerable, es la especie más capturada por la pesca submarina. El sector es descrito socioeconómicamente mediante la utilización de cuestionarios $(\mathrm{n}=179)$. Los resultados representan un estudio base que puede ayudar a la gestión del sector. No se encontraron evidencias científicas para justificar las restricciones espaciales actuales a los recursos de la pesca submarina.

Palabras clave: Pesca recreativa, gestión pesquera, ecosistema infralitoral, vulnerabilidad intrínseca, nivel trófico, Sparisoma cretense. 


\section{INTRODUCTION}

The different modalities of fishing all around the world, including recreational activities, have been identified as a major anthropogenic cause of marine habitat deterioration (Lewin et al. 2006; McPheeet al. 2002), impact on the equilibrium of the ecosystems (Agardy 2000; Coleman et al.2004; Lewin et al. 2006), and the overexploitation of resources (Coleman et al. 2004; Cooke and Cowx 2004). Recreational fishing is one of the most common leisure activities in coastal areas world-wide, involving several methods (e.g. boat-fishing, shore-fishing and spearfishing), large numbers of people and high levels of fishing effort (Lloret et al. 2008; Cowx 2002; Pitcher and Hollingworth 2002; Westera et al.2003). In particular, spearfishing has been repeatedly reported as a main cause of impact to the benthic fish communities that inhabit shallow rocky bottoms and coral reefs (Pita and Freire 2014, 2016; Lloret et al. 2008), thus lowering abundance and biomass of higher trophic level vulnerable species (Diogo and Pereira 2014; McPhee et al. 2002; Coleman et al. 2004; Lewin et al. 2006; Pita and Freire 2014). Very few studies, on the other hand, argue that spearfishing is ecologically sustainable because a diver is restricted to shallow water, is very selective and can target the species and size without the negative impacts of other fishing methods such as bycatch, bait, loss of gear and damage to habitat (Smith and Nakaya 2002).

Spearfishing is practiced in the Canary Islands by more than 6,500 people ( $0.3 \%$ of total population, $7 \%$ of total recreational fishing licences), and is spatially restricted by law to about $20 \%$ of the coastline. As many other islands across the world, the coastline of this archipelago is highly overcrowded and dependent on touristic and maritime leisure activities (Riera et al. 2016; Pascual Fernández et al. 2012), spearfishing being one among many of them. However, there is a total absence of empirical studies tackling the impact of spearfishing on infralittoral communities off The Canary Islands, apart from a technical report to Canary Islands Fishery Office (Castro-Hernández et al.2018) based on spearfishers opinions out of in situ interviews. There is also a study evaluating the spearfishing contests catches with information about species and their sizes in the catch (Martín-Sosa et al. 2018).

This is the first time that a study based on analysis of real catches from routine activity evaluates the impact of spearfishing on shallow infralittoral communities in The Canary Islands. The results constitute an important breakthrough in understanding the spearfishing effort levels in this archipelago, together with the amount of annual catches (biomass), catch-per-unit-effort and sizes in the catch. In addition, the present work analyses the trophic level and vulnerability of spearfishing target species. This may gives us clues about how the activity affects the ecosystem of shallow infralittoral communities. Finally, through a questionnaire, we draw a

* Spanish Institute of Oceanography, Canary Islands Oceanographic Centre, C/ Farola del Mar, 22, Dársena Pesquera, 38180 Santa Cruz de Tenerife, Spain. Corresponding author's e-mail: pablo.martin-sosa@ieo.es. 
socioeconomical picture of the spearfishing practitioners in the Canary Islands. The differences of the outcomes compared to previous studies are discussed, as well as the current spatial restriction of the activity as a management measure.

\section{MATERIAL AND METHODS}

\section{STUdy AREA}

The Canary Islands (Figure 1) are located in the Northeast Atlantic, between $27^{\circ}-29^{\circ} \mathrm{N}$ and $14^{\circ}-18^{\circ} \mathrm{W}$ (Hernández et al. 2013). The total coastline length of the archipelago is $1,501 \mathrm{~km}$. Due to the volcanic nature of the islands, their edifices have a significant slope, thus the island platforms (shallow bottoms of gentle slope located between 0 and $100 \mathrm{~m}$ depth) are limited in area compared to the land surface (Mitchel et al. 2002). The waters of the archipelago are situated on the eastern limit of the North Atlantic subtropical gyre, occupying an intermediate position between the rich cold upwelling waters of the northwest African coast and the warm and oligotrophic waters of the open ocean (Barton and Arístegui 2004). Limited island shelf and oligotrophic waters make the islands quite unfertile. This fact brings about fragile marine populations. On the other hand, the lengthy coastline, along with the rich and diverse coastal morphology, allows the occurrence and development of numerous different habitats and ecosystems (Hernández et al. 2013).

Spearfishing is permitted, without depth restriction (other than fishers apnea capacity, $90 \%$ of them cannot fish under $25 \mathrm{~m}$ of depth -results from this work questionnaires-), in around $20 \%$ of total coastline, divided in several open access zones by island (Figure 1). Both rocky and sandy bottoms are represented. Some of the areas have a difficult access from land and/or are far away from main coastal population spots. Zones at the north of the islands are also naturally restricted during great part of the year by exposure to adverse sea conditions (Yanes et al. 2006). The productive conditions and state of fish populations of the areas are heterogeneous, although in general stocks of interest in the Canary Islands are overfished (Castro et al. 2015).

\section{DATA COLLECTION \\ Catch and effort data}

The Asociación Canaria de Pescadores Submarinos Responsables (ACPESUR, Canarian Association for Responsible Spearfishers, translated to English) is the main spearfishers association in the Canary Islands, with just above 850 members, representing $13 \%$ of the total number of spearfishing licenses. ACPESUR designed a web app for their members to report their catches, and these results are used in the present study.

The members reporting information used belongs to fishing days performed during 2017 and 2018. A total of 958 reported catch entries were analyzed, taken 
from 623 fishing days, made by 104 spearfishers. $90 \%$ of the fishers taking part in the catch reporting have made between 5 and 25 entries. Most of the rest have made less than 5 entries. Fuerteventura, Gran Canaria and Tenerife Islands are better represented in the catch reporting, although there are catch reporting entries from every Canary Island. Information reported consisted of date, island, zone, fishing effort (in hours), the cause of zero catch, species caught and the size (total length for fishes and dorsal mantle length in the case of cephalopods) of each of the individuals (including a photograph with a metric reference). Entries from these two sample years without a photograph to check species identification and size were excluded from the analysis.

The biomass of the catch was calculated using weight-length relationships available in the literature or from the results of the sampling carried out at spearfishing contests made by Spanish Institute of Oceanography (SIO) (MartínSosa, unpublished data). Parameters $a$ and $b$ from these relationships are shown in Table 1. Finally, the mean catch per unit of effort (CPUE), expressed as weight of catch per spearfisher and hour of fishing, was calculated.

\section{Intrinsic vulnerability and trophic level data}

The intrinsic vulnerability of each fish species (Table 1) was obtained from Cheung et al. (2007). In the case of cephalopods, the work of Meissa and Gascuel (2015) was used. When the species information was not available, the intrinsic genus or family vulnerability was used. In some cases, the index of an ecologically very similar species of the same genus was considered the most appropriate to be used. Cheung et al. (2005) categorized fishes by their intrinsic vulnerability value in very high $(\operatorname{mode}=80)$, high $(\operatorname{mode}=60)$, moderate $(\operatorname{mode}=40)$ and low $($ mode $=20)$. The average intrinsic vulnerability value of the catch is brought about by calculating the arithmetic mean of intrinsic vulnerability index of each species weighted by their catch volume.

Available information on trophic levels from the literature of the taxa in the catch was used to assign a trophic level to each of the species fished by spearfishers (Table 1). Some of the trophic levels were available through FishBase (Froese and Pauly 2003). The trophic level expresses a position of an organism within the food web of the local marine ecosystem (Pauly and Christensen 2000). To estimate average trophic level in the catch we proceeded in the same manner than with intrinsic vulnerability index, calculating the mean arithmetic value for each taxa, weighted by its catch volume. 
ACPESUR members catch reporting also includes the size of each individual with an attached photograph including a metric reference. Minimum catch size was gathered for those regulated species (Table 1, MLL: Minimum Legal Length in $\mathrm{cm}$ of total length in the case of fishes, or dorsal mantle length for cephalopods).

González et al. (2012) attempted to gather all the available information about the biology and fishery of the main target species in the Canary Islands. This effort resulted in a scientific proposal for the conservation of a hundred species, thus establishing a minimum catch size based on biological knowledge (MSAL: Minimum Scientific Advised Length). These sizes have also been listed at Table 1, and used to check the percentage of immature individuals within the Canary Islands spearfishing catch.

\section{Socieconomic data}

ACPESUR, with the advice and collaboration of SIO, designed a questionnaire for their members to complete on the association web site, and these data were used in the present study. A total amount of 179 valid questionnaires were gathered. The answering period was 8 months, from July of 2018 to February of 2019. The main goal of the questionnaire was to know who practice spearfishing in the Canary Islands, how much effort is applied, when, where, how, and even why they fish. They were asked about the species they normally catch and the questionnaire finishes with a section of questions with the aim of describing what spearfishers think about their activity. Their opinion of these other matters is also requested: the fisheries management measures, other recreational modalities, the professional fishing sector, the state of fishery resources, surveillance, poaching, and especially, what they think about the Canary Islands spatially restricted access to resources for spearfishing.

\section{RESULTS}

\section{FISHING EFFORT AND YIELD DATA}

A total of 45 species have been reported to be fished by spearfishers (Table 1), belonging to 24 families, the majority being fishes, but also including two species of cephalopods (Loligo vulgaris and Sepia officinalis). Sparidae is the best represented family with 14 species. Only 2 species are pelagic, while 15 are benthopelagic, 13 demersal and 14 reef-associated. One diadromic fish (Chelon labrosus) was caught.

Sparisoma cretense is the top target species, both in terms of abundance and biomass (Figure 2, 35\% and 20\% of total catch respectively). The second most abundant species is Diplodus cervinus, although in terms of biomass, Seriola dumerili is actually the second due to its larger size, leaving D. cervinus in third place. 
Mean fishing effort is depicted in Figure 3. Spearfishers spend a mean 2.57 fishing hours per day, 1.48 mean days per month and 1.82 mean months per year. The effort is fairly consistent throughout the year, although the catch varies, being higher in summer months and November.

Over the 2 year period, the total reported catch is $654 \mathrm{~kg}$, 691 specimens, fished during 623 fishing journeys, almost half of which failed to have any catch. In annual terms, 52 fishers reported 311 fishing journeys with a total of 345 specimens fished and a total weight of $327 \mathrm{~kg}$. This means that the present study states 6.6 individuals and $6.3 \mathrm{~kg}$ per fisher and per year, a mean catch of just over $1 \mathrm{~kg}$ and 1 specimen per fisher per fishing day. If we make an extrapolation of this study's effort and catch results to the total number of spearfishing licenses in the Canary Islands, the total estimated spearfishing annual effort and catch is 39,700 days at sea and 42 tons respectively.

In terms of yield, 390 grams per fishing hour is the mean. If we look at the yield in the different islands, we can see ostensible differences, with a range from the $480 \mathrm{~g} / \mathrm{h}$ of Fuerteventura to the $212 \mathrm{~g} / \mathrm{h}$ of La Gomera Island (Figure 4).

\section{IMPACT ON INFRALITTORAL ASSEMBLAGES}

Spearfishing in the Canary Islands targets a wide range of sizes of the taxa present in the catch (Figure 5). There are specimens of Seriola dumerili, Muraena augusti, Dentex dentex, Pseudocaranx dentex, Sepia officinalis, Diplodus cervinus and Sparisoma cretense that have sizes closer to the Maximum Length (Lmax, Froese and Pauly 2003). With regard to small sizes, $1 \%$ of the catch is under the Minimum Legal Length (MLL, Table 1) and 10\% are under the Minimum Scientifically Advised Length (MSAL, Table 1, González et al. 2012), thus, expected to be immature. Epinephelus marginatus and Pagrus auriga deserve a special mention, since the totality of the specimens in the catch are under MSAL. 90\% of Mycteroperca fusca individuals in the catch are also under MSAL. Other species with more than half of the individuals in the catch under MSAL are Phycis phycis, Sarpa salpa, D. dentex and $D$. cervinus.

Although Balistes capriscus, Bodianus scrofa, D. dentex, E. marginatus, $M$. fusca and Pomatomus saltatrix are listed as vulnerable in the IUCN Red List, among the catch, none of the species are listed in the regional and national protected species catalogues. Moreover, vulnerability of the taxa in the catch is not uniform. In general, demersal coastal fish species of the Canary Islands are overfished to some extent (González 2008). Overfishing does not affect all species equally; it depends on their biological characteristics. Intrinsic Vulnerability Index (IVI) and trophic level (TL) were represented together (Figure 6) to show the range of these two variables within the catch, paying special attention to those species better represented in terms of abundance and biomass (highlighted black border circles). Trophic level in the catches ranges from just above 2 (Sarpa salpa, the only herbivorous species) to 4.5. Moreover, IVI is wide ranging, from less vulnerable (as the squid Loligo vulgaris) to highly vulnerable species (fishes as Tylosurus acus or Spondyliosoma cantharus). 
Species better represented in the catches in terms of abundance and biomass, though, have a wide TL range, but $90 \%$ of them are within a narrow IVI variation, from 30 to 50 (Figure 6). In fact, average TL and IVI in the catches, calculated by the mean arithmetic value for each taxa, weighted by its catch volume, is 3.24 and 45.72 respectively.

\section{SocioeCONOMics}

Fishermen age and experience distribution in the questionnaires are both bimodal (age $=26-30$ and 41-45 years old, time of experience $=5-10$ and $>20$ years, Figure 7) which suggests that spearfishers in the Canary Islands begin spearfishing at an approximate age of 20 . Half of them practice another recreational modality; $75 \%$ spearfishes are accompanied; $66 \%$ enter the sea from land, the rest by boat.

The majority fish between 10 and 70 times annually, mostly between 20 and 30 times annually. $60 \%$ fish all around the year, and $30 \%$ only in the summer. Only $10 \%$ of the spearfishers are capable of fishing below a depth of $20 \mathrm{~m}$. The 4 most important aspects influencing whether they fish or not, in this order, are: favourable climate conditions, work timetable, family commitments and desire to eat fish. 95\% has a clear conviction that spearfishing is important for household economy.

With respect to effort, the perception of $40 \%$ of fishers is they catch between 2 and 3 kilos per fishing day, while $25 \%$ think they fish $3-4 \mathrm{~kg}$ a day and $17 \%$ between 1 and $2 \mathrm{~kg}$. One third declares that they do not fish anything $20 \%$ of the fishing journeys, another third say that they don't catch anything up to $40 \%$ of the fishing days. Almost 3 quarters of the sector spend 3-4 hours fishing each fishing day, $20 \%$ usually fishing for a longer time, and an $8 \%$ making shorter journeys. In economic terms, almost $75 \%$ invest less than a thousand euro a year, $20-30 €$ per fishing day is the range of costs for the majority.

Concerning spearfishers thoughts and social behaviour, $48 \%$ of them admit not to reporting catches to the ACPESUR web platform although $99 \%$ think the Association is advantageous. Almost 90\% have never been sanctioned, 97\% see with good eyes a minimum size catch regulation, $72 \%$ don't know any spearfisher selling the catch. More than $75 \%$ consider themselves well informed about fishing regulations, by The Association, internet and friends, being the three main sources of information. $49 \%$ think that reporting catches is good for society to know about the activity, $35 \%$ think is good to collaborate with science. $70 \%$ think surveillance is insufficient, while half of them believe that in the Canary Islands sea resources are overfished. $70 \%$ clearly believe that the number of licenses for spearfishing is not the only factor responsible for a potential uploaded ecosystem charge capacity, but also the rest of the extractive sector. Relationship with other sectors can be summarized like this: recreational (land or boat), 63\% good or very good; professional fishers, $60 \%$ think is good or very good, the rest bad or very bad; the great majority have a good or very good relationship with swimmers (97\%) and divers (89\%).

In terms of fishing restrictions, most of them think Total Allowable Catch systems are good or very good fishing measures. Three quarters think temporal 
closures are beneficial, but only half of them think the same about spatial closures. To be more specific, $75 \%$ are against marine reserves of fishing interest, but $80 \%$ are in favour of no take zones. The great majority would like to be able to fish closer to their residence, $45 \%$ have the closest permitted area $10-25 \mathrm{~km}$ away from home, and $25 \%$ at a distance between 25 and $50 \mathrm{~km}$ from home.

When it comes to saying what they catch, information is quite reliable, since it's very similar to the real catch reported. There are fishermen declaring that they catch up to 15 different species. Although most than a half of the fishers think they still are catching the same species than years ago, several people think they are not getting the more desirable mid-high trophic level vulnerable species as Mycteroperca fusca, Epinephelus marginatus, Seriola dumerili or Pseudocaranx dentex anymore.

Regarding the spatial distribution of effort (Figure 1), in every island some zones are more visited than the others, having to do with proximity to residence, quality of the sea bottoms (too sandy and/or too deep) and sea conditions (wind and current exposure) most of the year, according to the fishermen themselves.

\section{DISCUSSION}

Fishing as a major worldwide cause of impact on habitats, ecosystems and species is unquestionable after results of so many scientific works (Lewin et al. 2006; McPhee et al. 2002; Agardy 2000; Coleman et al. 2004; Cooke and Cowx 2004). The impact of recreational fishing activities in coastal zones around the world, contributing to this reported detrimental effect, is also beyond doubt (Lloret et al. 2008; Cowx 2002; Pitcher and Hollingworth 2002; Westera et al. 2003). Although there are some works concluding the high and pernicious effect specifically of spearfishing on several coastal areas (Pita and Freire 2014, 2016; Lloret et al. 2008; Diogo and Pereira 2014; McPhee et al. 2002; Coleman et al.2004; Lewin $e t$ al. 2006), there are very few studies using real catch data from routine activity to assess this impact, being totally absent in the Canary Islands. This study is the first empirical research to assess the impact of spearfishing in the Canary Islands with more reliable data.

It is very difficult to monitor recreational fishing of any kind (Pascual Fernández et al. 2012), due to the lack of obligation of fishers to register their catches and of an official web of controlled landing spots, as professional fishers of the Canary Islands have. Most of the studies assessing impacts of recreational fishing in general and spearfishing in particular use polls as the only available method to obtain reliable information about the topic (Castro-Hernández et al. 2018; Lloret et al. 2008; Lloret and Font 2013) or real catches from contests, where rules bias results (Martín-Sosa et al. 2018; Darmanin and Vella 2018; Boada et al. 2017).

Collaboration with Asociación Canaria de Pescadores Submarinos Responsables (ACPESUR) has allowed us access to more reliable information concerning routine activity. This fact does not preclude the work from different constraints and sources of error or bias which confer a certain degree of uncertainty to the results. The way data has been collected, including a picture of every single catch integrated in the 
analysis, avoids uncertainty about species identification and sizes. Nevertheless, we have to take into account that the $13 \%$ of associated spearfishers must be the most responsible part of the sector. Moreover, those reporting catches are evidently the most aware of sustainability. It is true that any time an activity is the subject of assessment, it is impossible to monitor poaching when methods depend on willingness and collaboration.

Another source of bias when it comes to quantify the activity's pressure is the lack of knowledge about what percentage of the fishing journeys is being registered by those spearfishers reporting their catch. This could be a probable source of under estimation. We assume the results as an average of the real picture that takes place in real terms. To end with those questions which need to be taken into account to interpret these results, we have to understand that the activity is putting pressure on an already overfished environment, with unbalanced ecosystems, disturbed habitats and modified natural food webs, so the catch profile is influenced by this fact.

Results tell us spearfishing in the Canary Islands is not an activity specially focused on just a few high trophic level vulnerable species. The list of target species is quite long and diverse, with species from different families and habitats. One single species, Sparisoma cretense, the parrotfish, features prominently in a great part of the activity. Fishing effort figures found are lower than those detected in other places (data from surveys, 3.7 hours per fishing day, Lloret et al. 2008) or in the Canary Islands (data from surveys, 3.3 hours per fishing day, Castro-Hernández et al. 2018). The Eastern islands (shaded in grey in Figure 4), that are more influenced by the African coastal upwelling (Valdés and González-Déniz 2015), are more productive. Tenerife and La Palma Islands, although being less fruitful, are two western islands with more experienced spearfishers (according to the results of this study questionnaires), therefore having higher yields than expected. Catch and yield results comparisons between this study and that of Castro-Hernández et al. (2018) follow the same trend. This study's outputs are $1.1 \mathrm{~kg}$ per fishing day (3.3 at the previous study) and $390 \mathrm{~g}$ per hour (654 at Castro-Hernández et al. (2018), 542 at Pascual Fernández et al. (2012)). Both studies cited are based on polls. Data from questionnaires used in this study tell us, comparing to reporting catch data by the same fishers, that when they are asked about their catches, they tend to overestimate them. This is, therefore, the most plausible explanation for the disparities. Differences in the average yield among islands (from $480 \mathrm{~g} / \mathrm{h}$ in Fuerteventura to 210 in La Gomera) highlight the importance of using information from the whole archipelago when it comes to assess the activity's pressure and impact in general at Canary Islands. As an example, Pascual-Fernández et al. (2012) is a study focused in Tenerife, and cannot be used to assess the activity in the whole archipelago. In fact, authors are about to implement the poll all over the 8 islands (Pascual-Fernández, pers. comm.). The total estimated spearfishing annual catch of 42 tons, making an extrapolation of this study's catch results to the total number of spearfishing licenses in the Canary Islands, is clearly below the around 800 tons estimated by Castro-Hernández et al. (2018). This catch estimate means not even $0.3 \%$ of annual landings of artisanal fishing sector (official Canary Islands Fishery Office data from landing spots registering system). The importance of spearfishing 
in extracted biomass terms, compared to that of the total fishing sector extraction, is certainly limited. These results are totally different to those of previous research, not only in the Canary Islands (Castro-Hernández et al. 2018) but also in other parts of the world (Passley et al. 2010). Again, the reason can be the usual tendency of fishermen to exaggerate when asked about the amount of their catches in polls, surveys or interviews (as it can be checked with the comparison between the real catch reported and the fishers opinion on their catches in the questionnaires of this study). Average yield found in this study is very similar to that carried out by recreational land-fishers in the El Hierro Marine Reserve in Martín-Sosa et al. 2008, with a methodology of real catch sampling as it has been performed for this study. Taking a look to the species composition, the direct competence between spearfishing and professional artisanal fisheries in the Canary Islands is clear, akin to other places in Spain (Lloret and Font 2013). The same happens with the rest of modalities of recreational fisheries (Pascual Fernández et al. 2012). However, in the case of spearfishing, the estimated total biomass extraction is not significant compared to that of professional artisanal fisheries. This is not the case in other studies around the world (Rocklin et al. 2011). Recreational fisheries still aim the same resources as professional artisanal fishers, competing directly with this sector. It is a sector technically better equipped, developed with no kind of monitoring, and with a total number of 90,000 licences (Canary Islands Government data, http:// www.gobiernodecanarias.org/agricultura/pesca/temas/pesca_recreativa/licencias. html, 45 recreational licences per 1,000 people), more than a hundred times the volume (in number of units) of professional artisanal fisheries.

The effect of spearfishing on the size of specimens is remarkable. It is referred as one focusing on large individuals of certain species (Lloret et al. 2008; Sluka and Sullivan 1998; Assis et al. 2017; Mann et al. 1997; Harper et al. 2000). This effect can be seen in our results, but only for isolated catches. The same happens with catches at contests in the Canary Islands (Martín-Sosa et al. 2018), even though participants are specifically trained at a higher level of expertise. We are unable to conclude that spearfishing in the Canary Islands nowadays is focusing on large spawners of any species. Since spearfishers find large specimens attractive, but these are not abundant in the catches, there could be two reasons: because of overfishing, but also as a consequence of the difficulties for spearfishers to catch large specimens. This is due to their great mobility and capacity to recognize speafishers and spearguns and escape to greater depths, as Sbragaglia et al. (2018) have proved. These large fish are caught by other fishing modalities where there is no fisher recognition. It has been noted that spearfishers in the Canary Islands are aware of the harm of fishing small size individuals, but are totally unaware of the danger of focusing on large highly fecund specimens.

Regarding small sizes, the results of this study are worrying, not in general to the catch, but in the case of some important species from an ecological perspective such as Epinephelus marginatus, Pagrus auriga or Mycteroperca fusca. In the case of Diplodus cervinus, more than half of the individuals in the catch are under Minimum Scientifically Advised Length (MSAL, cm of Total Length or Dorsal Mantle Length). Although it is true that illegal sizes in the catch are rare, both in the contests (Martín- 
Sosa et al. 2018) and during routine activity, as this study concludes, it is remarkable that in the case of some target species, Minimum legal length (MLL, cm of Total Length or Dorsal Mantle Length) is set not relying on scientific information on the species and should be changed to a closer size to MSAL (González et al. 2012), if not MSAL itself. The MSAL is large for species like Epinephelus marginatus, Pagrus auriga or Mycteroperca fusca because of their sequential hermaphroditism bringing about highly imbalanced sex ratios as a consequence of fishing. The other gross legal limitation referring to MLL is the noticeable scarce number of regulated species. These two facts make legal the majority of spearfishing catches although the presence of immature specimens in the catch is worrying for certain species. During the process of this study, the Canary Islands Fishery Office has taken steps towards a new MLL regulation which includes many more species and in most of the cases with MLL much closer to MSAL, following the advice given by the author of this work based on the findings of Gonzalez et al. (2012).

Referring to the biological characteristics of spearfishing catch, taking into account the results of other studies in the Mediterranean (Lloret et al. 2008) (previous studies on the matter do not exist in the Canary Islands), a greater average trophic level (TL) and Intrinsic Vulnerability Index (IVI) was expected. An average TL and IVI of 3.24 and 45.72 respectively are not describing a catch mainly consisting in slow growing vulnerable apex predators. On the other hand, the averages belong to a moderately vulnerable carnivorous species placed not very high in the trophic pyramid. Moreover, parrotfish, a fast growing mid trophic level not so vulnerable fish, typical from the Canary Islands rocky coastal habitats, is at the top of spearfishing catches with a clearly greater abundance and biomass than the rest of target species. Nevertheless, in the Canary Islands there is a total lack of recurring scientific program to assess fisheries. The existing efforts are isolated and inconsistent. The scattered, disperse and partial information these few studies provide, together with the expert knowledge of the majority of fishery experts in the Canary Islands were used in 2008 to certify a severe and generalized over fishing status of the Canary Islands fishery resources (González 2008). Some studies have been performed to prove that overfishing results in affected marine food webs. This results in lowered trophic levels, with the predominant subsistence of less vulnerable species. The highest trophic levels and most vulnerable species mainly undergo the effects of overfishing. This process is known as "fishing down the marine food webs" (Pauly and Palomares 2005; De Lope Arias et al.2016; Stergiou 2005; Meissa and Gascuel 2015; Pauly and Watson 2005). This current situation, normal in overfished fishing grounds, is swaying the trophic and vulnerability profile of today's artisanal and recreational fisheries catches all over the world; the Canary Islands are no exception.

Spearfishers as a sector in the Canary Islands meet a theoretical image of a recreational sector. Levels of effort and catch are those appropriate to a leisure activity, although fishing as a food source is a more than expected important incentive. Spearfishers are young and generally belong to the lower middle class who do not have high expenditure during their routine activity. In socioeconomic terms spearfishing in the Canary Islands is a sector fairly concerned about marine sustainability, with growing levels of partnership thanks to the existence of ACPESUR, a responsible 
spearfishers association, built around a main goal: achieving $100 \%$ of non protected open access coastline. The barriers to access the resources totally predetermine the activity. These are remoteness, difficult access and bad quality of the zones: a nightmare for spearfishers. Regarding the spatial distribution of effort (Figure 1), from the 2 zones of El Hierro Island, $\mathrm{H} 2$ is the most visited ( $\mathrm{H} 1$ is very exposed to NE dominant winds). More than half of Fuerteventura spearfishers visit zone F2 more frequently, since is the only one protected from wind exposure among the 4 zones of the island. In Gran Canaria and Lanzarote Islands there is an equitable distribution of spearfishing visits among all the zones. The high degree of exposure of G1 spearfishing zone in La Gomera marks zone G2 as almost the only one visited. In La Palma, the most unexposed zone is far away from the capital and most of it is also closed half of the year. Of among the other 3 zones, the most visited $(60 \%)$ is the closest to the capital, P3. Finally, Tenerife, with 9 fishing zones, is a mixture of exposed, little productive and remote zones. The ones with better conditions taking into account these three factors are the most visited (T9, T2 and T5, in this order). As in other coastal activities, poaching exists to some extent, with fishing journeys that are over quota, fishing at closed access coast, and especially, illegal direct sell of catch to restaurants. As a consequence, spearfishing has gained the image of a black devil affecting the relationship with professional artisanal fishers, a body that, in the opinion of spearfishers, should not have favourable access to all public fishing resources in the Canary Islands. With the results of this study in hand it seems too daring to blame spearfishing for the artisanal fisheries decline and to attribute the overexploitation of some rocky coastal demersal resources solely to spearfishing.

We understand existence of ACPESUR is beneficial, and the partnership with scientists gives the leading edge to the future of the sector. It is a way to monitor and assess the activity, to educate about some yet unacquired responsible fishing habits, and to modify contests minimum weight for some species with a big divergence between MLL and MSAL. Deconstructing the process of fishing from the fishers' perspective can help fisheries researchers understand social-ecological interactions and identify leverage points for management (Pavlowich and Kapuscinski 2017). In Lloret et al. (2016), it is concluded that it is necessary to integrate different assessment approaches (biological, social and economic), with active participation from stakeholders, governments and relevant research institutions, to better evaluate and manage coastal fisheries. This study should be useful for this purpose and the Canary Islands and Spanish governments, who share the management of fisheries in the Canary Islands, must take note. Managers must assess the consequences of maintaining the current spearfishing access system or putting in practice an alternative open access. The latter would bring about an increased but more disperse spearfishing effort. The first option doesn't seem to be justified by any scientific evidence. We don't find a scientific reason for spearfishing being the only fishing activity in the Canary Islands with restricted access zones to available resources, when it is already an activity limited by $5 \mathrm{~kg}$ per person and fishing day. CastroHernández et al. (2018), the only study in the Canary Islands trying to assess the impact of the activity with visual censuses, show significant higher species richness in zones of the Canary Islands where spearfishing is allowed and no significant size 
differences between these zones and control ones. These conclusions support our results, as other studies in the rest of Spain, like Pita and Freire (2016) in Galicia or Boada et al. (2017) in Catalonia, both based on contest information, which conclude limited or nil impact of spearfishing on fish populations and community composition. Research should be carried out on the potential increase of spearfishing biomass extraction in a scenario whereby total open access would be set up in the Canary Islands. It is vital, finally, to stress the importance of having scientific reliable information to manage fisheries. The scarcer the information is, the more crucial the application of the precautionary principle becomes.

\section{ACKNOWLEDGEMENTS}

I would like to thank Asociación Canaria de Pescadores Submarinos Responsables (ACPESUR, http://asociacioncanariapescadoressubmarinosresponsables.com/) and to all the spearfishers reporting information to this study, in special to Ovidio Pérez, Héctor de Paz and Gustavo Monterrey. I also thank Santiago Barreiro for map editing and Laura Martín and Gustavo Monterrey for help with data analysis. I appreciate Catherine Mooney's help with English corrections.

\section{AUTHORS CONTRIBUTION}

The author is the only responsible for the whole paper. Some little contributions have been considered in Acknowledgements Section. 


\section{REFERENCES}

Agardy, T. 2000. Effects of fisheries on marine ecosystems: a conservationist's perspective. ICES J. Mar. Sci., 57, 761-765. doi:10.1006/jmsc.2000.0721

Andrade, A.B., Machado, L.F., Hostim-Silva, M. \& Barreiros, J.P. 2003. Reproductive biology of the dusky grouper Epinephelus marginatus (Lowe, 1834). Braz. Arch. Biol. Techn., 46(3), 373-381. doi: 10.1590/S1516-89132003000300009

Assis, J., Gonçalves, J.M., Veiga, P. \& Pita, C. 2017. Spearfishing in Portugal: A baseline study on spearfishers' profiles, habits and perceptions towards management measures. Fisheries Manag. Ecol., 1-12. doi: 10.1111/fme.12313

Balkis, S., Ben Salem, M., Reynaud, C. \& Capapé, C. 2014. Diet of Mediterranean Moray, Muraena helena (Actinopterygii: Anguilliformes: Muraenidae), from the North-Eastern Tunisian Coast (Central Mediterranean). Acta Ichthyol. Piscat., 44 (4), 273-283. doi: 10.3750/AIP2014.44.4.01.

Barton, E.D. \& Arístegui, J. 2004. The Canary Islands coastal transition zone-upwelling eddies and filaments. Prog. Oceanogr., 62, 67-69. doi: 10.1016/j.pocean.2004.08.003.

Ben-Tuvia, A. 1986. “Mugilidae.” In: Whitehead, P.J.P.,Bauchot, M.-L., Hureau, J.-C., Nielsen, J. \& Tortonese, E. (eds.) Fishes of the North-eastern Atlantic and the Mediterranean, vol. III (pp. 1197-1204). Paris: UNESCO.

Ben-Tuvia, A. 1986. “Sphyraenidae.” In: Whitehead, P.J.P., Bauchot, M.-L., Hureau, J.-C., Nielsen, J., Tortonese, E. (eds.) Fishes of the North-eastern Atlantic and the Mediterranean, vol. III (pp. 1194-1196). Paris: UNESCO.

Ben-Tuvia, A. \& McKay, R. 1986. “Haemulidae.” In: Whitehead, P.J.P.,Bauchot, M.-L., Hureau, J.-C., Nielsen, J. \& Tortonese, E. (eds.) Fishes of the North-eastern Atlantic and the Mediterranean, vol. II (pp. 858-864). Paris: UNESCO.

Boada, J., Sagué, Ó. \& Gordoa, A. 2017. Spearfishing data reveals the littoral fish communities' association to coastal configuration. Estuar. Coast. Shelf Sci., 199, 152-160. doi: 10.1016/j. ecss.2017.10.007

Bouchon-Navaro, Y., Bouchon, C., Kopp, D. \& Louis, M. 2006. Weight-length relationships for 50 fish species collected in seagrass beds of the Lesser Antilles. J. Appl. Ichthyol., 22, 322324. doi: 10.1111/j.1439-0426.2006.00715.x.

Bustos, R., Luque, Á. \& Pajuelo, J.G. 2010. Reproductive biology of the island grouper (Mycteroperca fusca) in the Canary Islands, northwest coast of Africa. Sci. Mar., 74(3), 613-619.

Caldentey, M.A. 1987. Estudio de la biología de la boga (Boops boops (Linnaeus, 1758)) de las costas de Tenerife. [M. Sc. Thesis], University of La Laguna: 101 pp.

Castro, J.J., Divovich, E., Delgado de Molina Acevedo, A. \& Barrera-Luján, A. 2015. Overlooked and under-reported: A catch reconstruction of marine fisheries in the Canary Islands, Spain, 1950-2010. Univ. British Columbia Work. Paper Series, 26, 26 pp.

Castro, J.J., Santiago, J.A., Hernández-García, V. \& Pla, C. 1999. Growth and reproduction of the dolphinfish (Corphaena equiselis and Coryphaena hippurus) in the Canary Islands, Central-East Atlantic (preliminary results). Sci. Mar., 63 (3-4), 317-325. doi: 10.3989/ scimar.1999.63n3-4327. 
Castro-Hernández, J.J., Jiménez-Alvarado, D., Guerra-Marrero, A. \& Sarmiento-LezCANO, A. 2018. Estimación del impacto de la pesca submarina de recreo en las zonas acotadas para dicha actividad en el Archipiélago Canario. Universidad de Las Palmas, Instituto Universitario EcoAqua. Dirección General de Pesca. Gobierno de Canarias.

Cengiz, Ö. 2013. Some biological characteristics of Atlantic bonito (Sardasarda Bloch, 1793) from Gallipoli Peninsula and Dardanelles (northeastern Mediterranean, Turkey). Turk. J. Zool., 37, 73-83. doi: 10.3906/zoo-1204-10.

Châari, M., Boudaya, L. \& Neifar, L. 2016. Preliminary observations on the feeding habits of the Mediterranean needlefish Tylosurusacusimperialis. J. Coast. Life Med., 4(6), 426-429. doi: 10.12980/jclm.4.2016J6-32.

Cheung, W.W., Pitcher, T.J. \& Pauly, D. 2005. A fuzzy logic expert system to estimate intrinsic extinction vulnerabilities of marine fishes to fishing. Biol. Conserv., 124, 97-111. doi: 10.1016/j.biocon.2005.01.017.

Cheung, W.W., Watson, R., Morato, T., Pitcher, T.J. \& Pauly, D. 2007. Intrinsic vulnerability in the global fish catch. Mar. Ecol. Prog. Ser., 333, 1-12. doi: 10.3354/meps333001.

Chikaraishi, Y., Steffan, S.A., Ogawa, N.O., Ishikawa, N.F., Sasaki, Y., Tsuchiya, M. \& Ohkouchi, N. 2014. High-resolution food webs based on nitrogen isotopic composition of amino acids. Ecol. Evol., 4(12), 2423-2449. doi: 10.1002/ece3.1103.

Coleman, F.C., Figueira, W.F., Ueland, J.S. \& Crowder, L.B. 2004. The Impact of United States Recreational Fisheries on Marine Fish Populations. Science, 305 (5692): 1958-60. doi: $10.1126 /$ science.1100397.

Cooke, S.J. \& Cowx, I.G. 2004. The Role of Recreational Fishing in Global Fish Crises. BioScience, 54 (9), 857-859. doi: 10.1641/0006-35682004054[0857:TRORFI]2.0.CO;2.

Cowx, I.G. 2002. Recreational fisheries. In P. Hart,J. D. Reynolds (Eds.), Handb. Fish Biol. Fish. (vol. II, pp. 367-390). Oxford: Blackwell Science.

Darmanin, S.A. \& Vella, A. 2018. An assessment of catches of shore sport fishing competitions along the coast of the Maltese Islands: Implications for conservation and management. Fisheries Manag. Ecol., 1-9. doi: 10.1111/fme.12271.

De Lope Arias, J.J., Mateu-Vicens, G. \& Deudero Company, S. 2016. Meta-analysis review of fish trophic levels in marine protected areas based on stable isotope data. Medit. Mar. Sci., 17 (2), 496-507.doi: $10.12681 / \mathrm{mms} .1628$.

De Sylva, D.P. 1990. “Sphyraenidae.” In: Quero, J.C., Hureau, J.C., Karrer, C., Post, A., Saldanha, L. (eds.) Check-list of the fishes of the eastern tropical Atlantic (CLOFETA), vol. 2 (pp. 860 864). Lisbon: JNICT; Paris: SEI; Paris: UNESCO.

Delgado, A., García, M.T., Rodríguez, E. \& López Abellán, J.L. 1983. Plan regional de evaluación de recursos pesqueros. Provincia de Santa Cruz de Tenerife, vol. 2. Pelágicos costeros. Consejería de Agricultura y Pesca del Gobierno de Canarias.

Diogo, H. \& Pereira, J.G. 2014. Assessing the potential biological implications of recreational inshore fisheries on sub-tidal fish communities of Azores (north-east Atlantic Ocean) using catch and effort data. J. Fish Biol., 84, 952-970. doi: 10.1111/jfb.12336.

Fischer, W., Sousa, I., Silva, C., de Freitas, A., Poutiers, J.M., Schneider, W., Borges, T.C., Feral, J.P. \& Massinga, A. 1990. Fichas FAO de identificaçao de espécies para actividades de pesca. Guia de campo das espécies comerciais marinhas e de águas salobras de Moçambique. Publicaçao preparada em collaboraçao com o Instituto de Investigaçao 
Pesquiera de Moçambique, com financiamento do Projecto PNUD/FAO MOZ/86/030 e de NORAD. Roma, FAO. 1990. 424 p.

Frimodt, C. 1995. Multilingual illustrated guide to the world's commercial warmwater fish. Osney Mead, Oxford, England: Fishing News Books.

Froese, R. \& Pauly, D. 2003. FishBase. Retrieved 02 23, 2019, from http://www.fishbase.de.

Frota, L.O., Costa, P.A.S. \& Braga, A.C. 2004. Length-weight relationships of marine fishes from the central Brazilian coast. NAGA WorldFishCenter Quarterly. 27(1\&2), 20-26. doi: $10.12681 / \mathrm{mms} .463$.

García, C.B. \& Contreras, C.C. 2011. Trophic levels of fish species of commercial importance in the Colombian Caribbean. Rev. Biol. Trop., 59(3), 1195-1203. doi: 10.15517/rbt.v0i0.3391.

Gomon, M.F. \& Forsyth, P. 1990. “Labridae.” In: Quero, J.C., Hureau, J.C., Karrer, C., Post, A., Saldanha, L. (eds.) Check-list of the fishes of the eastern tropical Atlantic (CLOFETA), vol. 2 (pp. 860-864). Lisbon: JNICT; Paris: SEI; Paris: UNESCO.

Gonçalves, J.M.S., Bentes, L., Lino, P.G., Ribeiro, J., Canário, A.V.M. \& Erzini, K. 1997. Weight-length relationships for selected fish species of the small-scale demersal fisheries of the south and south-west coast of Portugal. Fish. Res., 30(3), 253-256. doi: 10.1016/S01657836(96)00569-3.

González, J.A. 1991. Biología y pesquería de la Vieja, Sparisoma (Euscarus) cretense (Linnaeus, 1758) (Osteichthyes, Scaridae), en las Islas Canarias. [Ph. D. Thesis], University of La Laguna.

GonzÁlez, J.A. 2008. Estado de los Recursos Pesqueros de Canarias (REPESCAN). Telde (Las Palmas): Instituto Canario de Ciencias Marinas, Agencia Canaria de Investigación, Innovación y Sociedad de la Información, Gobierno de Canarias.

González, J.A., Pajuelo, J.G., Lorenzo, J.M., Santana, J.I., Tuset, V.M. \& Jiménez, S., et al. 2012. Talla Minima de Captura de peces, crustáceos y moluscos de interés pesquero en Canarias. Una propuesta cientifica para su conservación. (J.A. González, J.G. Pajuelo, J.M. Lorenzo, eds.) Las Palmas de Gran Canaria: Viceconsejería de Pesca del Gobierno de Canarias.

González, J.A., Santana, J.I., Rodríguez, M., Marrero, M.F., Gimeno, M., González-Cuadrado, R., Pérez-Peñalvo, J.A., García Mederos, A.M., Jiménez, S. \& Lozano, I.J. 2004. Impacto sobre la moratoria de pesca con nasas tradicionales sobre los recursos pesqueros en el caladero de Fuerteventura. Resultados de la campańa de seguimiento 2003. Final Cientific-Technical Report. Departamento de Biología Pesquera del Instituto Canario de Ciencias Marinas-Universidad de La Laguna: 53 pp.

Greenfield, D.W. 1981. "Holocentridae.” In W. Fischer, G. BianchiW.B. Scott (eds.) FAO species identification sheets for fishery purposes. Eastern Central Atlantic; fishing areas 34, 47 (in part) Vol. 2. Department of Fisheries and Oceans Canada and FAO.

Guerra, Á. 2006. Ecology of Sepia officinalis. VieMilieu, 56 (2), 97-107.

Guerra, Á. \& Rocha, F. 1994. The life history of Loligo vulgaris and Loligo forbesi (Cephalopoda: Loliginidae) in Galician waters (NW Spain). Fish. Res., 21(1-2), 43-69. doi: 10.1016/01657836(94)90095-7.

Guidetti, P. \& Boero, F. 2002. Spatio-temporal variability in abundance of the parrotfish, Sparisoma cretense, in SE Apulia (SE Italy, Mediterranean Sea). Ital. J. Zool., 69, 229-232. doi: 10.1080/11250000209356464. 
Harmelin-Vivien, M.L. \& Quéro, J.-C. 1990. “Balistidae.” In: Quero, J.C., Hureau, J.C., Karrer, C., Post, A., Saldanha, L. (eds.) Check-list of the fishes of the eastern tropical Atlantic (CLOFETA), vol. 2 (pp. 860-864). Lisbon: JNICT; Paris: SEI; Paris: UNESCO.

Harper, D.E., Bohnsack, J.A. \& Lockwood, B.R. 2000. Recreational Fisheries in Biscayne National Park, Florida, 1976-1991. Mar. Fish. Rev., 62 (1), 8-26.

Hernández, J.C., Clemente, S., Tuya, F., Pérez-Ruzafa, Á., Sangil, C., Moro-Abad, L., et al. 2013. Echinoderms of the Canary Islands, Spain. In: Alvarado, J.J., Solís-Marín, F.A. (eds.). Echinoderm Research and Diversity in Latin America (pp. 471-510). Berlin Heidelberg: Springer-Verlag.

IGFA. 2009. Database of IGFA angling records until 2009. Fort Lauderdale, USA: IGFA.

Jennings, S. \& VAn Der Molen, J. 2015. Trophic levels of marine consumers from nitrogen stable isotope analysis: estimation and uncertainty. ICES J. Mar. Sci., 72(8), 2289-2300. 10.1093/ icesjms/fsv120.

Jiménez, S. 1997. Taxonomía, biología y pesca de las especies de la familia Muraenidae (Osteichthyes, Anguilliformes) en las islas Canarias. [Tesis doctoral]. Universidad de La Laguna, Departamento de Biología Animal, U.D.I. de Ciencias Marinas.

Lasso, J. \& Zapata, L. 1999. Fisheries and biology of Coryphaena hippurus (Pisces: Coryphaenidae) in the Pacific coast of Colombia and Panama. Sci. Mar., 63(3-4), 387-399. doi: doi. org/10.3989/scimar.1999.63n3-4387.

Lewin, W.-C., Arlinghaus, R. \& Mehner, T. 2006. Documented and Potential Biological Impacts of Recreational Fishing: Insights for Management and Conservation. Rev. Fish. Sci., 14, 305-367. doi: 10.1080/10641260600886455.

Lloret, J. \& Font, T. 2013. A comparative analysis between recreational and artisanal fisheries in a Mediterranean coastal area. Fish.Manag. Ecol., 20, 148-160. doi: 10.1111/j.13652400.2012.00868.x.

Lloret, J., Cowx, I.G., Cabral, H., Castro, M., Font, T. \& Gonçalves, J.M., et al. 2016. Small-scale coastal fisheries in European Seas are not what they were: Ecological, social and economic changes. Mar. Pol., doi: 10.1016/j.marpol.2016.11.007. doi: 10.1016/j. marpol.2016.11.007.

Lloret, J., Zaragoza, N., Caballero, D., Font, T., Casadevall, M. \& Riera, V. 2008. Spearfishing pressure on fish communities in rocky coastal habitats in a Mediterranean marine protected area. Fish. Res., 84-91. doi: 10.1016/j.fishres.2008.07.002.

Lorenzo, J.M., Pajuelo, J.G., Méndez-Villamil, M., Coca, J. \& Ramos, A.G. 2002. Age, growth, reproduction and mortality of the striped seabream, Lithognathus mormyrus (Pices, Sparidae), off the Canary Islands (Central-east Atlantic). J. Appl. Ichthyol., 18(3), 204-209. doi: 10.1046/j.1439-0426.2002.00318.x.

Lozano, I.J. (coord.). 1993. Biología de especies comerciales profundas de Canarias. Final Report. Comisión de las Comunidades Europeas. Study contract among ULLDBA-ICCMULPGCDB-IEO y DG XIV/C/1, 1992/7.

Maigret, J. \& Ly, B. 1986. Lespoissons de mer de Mauritanie. Compiègne: Science Nat.

Mann, B.Q., Scott, G.M., Mann-Lang, G.B., Brouwer, S.L., Lamberth, S.J., Sauer, W.H., et al. 1997. An evaluation of participation in and management of the South African spearfishery. S. Afr. J. Marine Sci., 18 (1), 179-193. doi: 10.2989/025776197784161144. 
Martín-Sosa, P., Cansado, S., Falcón, J.M., González-Lorenzo, J.G., Jurado-Ruzafa, A., Villegas, N., et al. 2008. El impacto de la pesca recreativa en las reservas marinas: La Reserva Marina de Punta de La Restinga -Mar de Las Calmas- (El Hierro, Islas Canarias) como caso de estudio. Proceedings of XV Simposio Ibérico de Estudios de Biología Marina. Funchal, Madeira, Portugal.

Martín-Sosa, P., Cansado, S., Fernández, M.A.R. \& Villegas, N. 2006. Seguimiento científico del efecto de la Reserva Marina de La Palma (Islas Canarias). Resultados de la Campaña de Prospección Pesquera "PEXLAPALMA 2006". Instituto Español de Oceanografía, Centro Oceanográfico de Canarias. Memoria científico-técnica final, 59 pp. + Anexes.

Martín-Sosa, P., Hernández-Rodríguez, E., Hernández-González, C., Jurado-Ruzafa, A., GonzÁlez-Lorenzo, G., JimÉnez-Navarro, S., et al. 2018. Canaries spear fishing contests sampling. I International Symposium on Marine Recreational Fishing Proceedings. Vigo, Spain.

McClanahan, T.R. \& Branch, G.M. 2008. Food webs and the dynamics of marine reefs. New York: Oxford University Press.

McDowall, R.M. 1997. The evolution of diadromy in fishes (revisited) and its place in phylogenetic analysis. Rev. Fish Biol. Fish., 7(4), 443-462. doi: 10.1023/A:1018404331601.

McPhee, D.P., Leadbitter, D. \& Skilleter, G.A. 2002. Swallowing the bait: is recreational fishing in Australia ecologically sustainable? Pacific Conserv. Biol., 8, 40-51. doi: 10.1071/ PC020040.

Meissa, B. \& Gascuel, D. 2015. Overfishing of marine resources: some lessons from the assessment of demersal stocks off Mauritania. ICES J. Mar. Sci., 72 (2), 414-427. doi: 10.1093/icesjms/ fsu144.

Méndez-Villamil, M., Lorenzo, J.M., Pajuelo, J.G., Ramos, A.G. \& Coca, J. 2002. Aspects of the life history of the salema, Sarpa salpa (Pisces, Sparidae), off the Canarian Archipielago (central-east Atlantic). Environ. Biol. Fish., 63, 183-192. doi: 10.1023/A:1014216000459.

Mitchel, N.C., Masson, D.G., Watts, A.B., Gee, M.J. \& Urgeles, R. 2002. The morphology of submarine flanks of volcanic islands. A comparative study of the Canary and Hawaiian hotspot islands. J. Volcanol. Geoth. Res., 115, 83-107. doi: 10.1016/S0377-0273(01)00310-9.

Morales-Nin, B. \& Moranta, J. 1997. Life history and fishery of the common dentex (Dentex dentex) in Mallorca (Balearic Islands, western Mediterranean). Fish. Res., 30(1-2), 67-76. doi: 10.1016/S0165-7836(96)00560-7.

Morey, G., Moranta, J., Massutí, E., Grau, A., Linde, M., Riera, F. \& Morales-Nin, B. 2003. Weight-length relationships of littoral to lower slope fishes from the western Mediterranean. Fish. Res., 62(1), 89-96. doi: 10.1016/S0165-7836(02)00250-3.

Mundy, B.C. 2005. Checklist of the fishes of the Hawaiian Archipelago. Bishop Mus. Bull. Zool., 6, 1-704.

Murie, D.J. \& Parkyn, D.C. 2008. Age, growth and sex maturity of Greater Amberjack (Seriola dumerili) in the Gulf of Mexico. SEDAR33-RD13. SEDAR, North Charleston, SC. 41 pp.

Oliveira, M.T., Santos, M.N., Coelho, R., Monteiro, V., Martins, A. \& Lino, P.G. 2015. Weight-length and length-length relationships for reef fish species from the Cape Verde archipelago (tropical north-eastern Atlantic). J. Appl. Ichth., 31(1), 236-241. doi: 10.1111/ jai.12497.

Pajuelo, J.G. 1997. La pesquería artesanal canaria de especies demersales: Análisis y ensayo de dos modelos de evaluación. [Ph. D. Thesis], University of Las Palmas de Gran Canaria: 347 pp. 
Pajuelo, J.G. \& Lorenzo, J.M. 1999. Life history of black seabream, Spondyliosoma cantharus, off the Canary Islands, Central-east Atlantic. Environ. Biol. Fish., 54, 325-336. doi: 10.1023/A:1007515301745.

Pajuelo, J.G. \& Lorenzo, J.M. 2004. Basic characteristic of the population dynamics and state of explotation of Moroccan white seabream Diplodus sargus cadenati (Sparidae) off Canarian Archipelago. J. Appl. Ichth., 20 (1), 15-21. doi: 10.1046/j.0175-8659.2003.00540.x.

Pajuelo, J.G., Socorro, J., GonzÁlez, J.A., Lorenzo, J.M., Pérez-Peñalvo, J.A., Martínez, I. \& Hernández-Cruz, C.M. 2006. Life history of the red-banded seabream Pagrus auriga (Sparidae) from the coasts of the Canarian archipelago. J. Appl. Ichth., 22, 430-436. doi: 10.1111/j.1439-0426.2006.00748.x.

Pan, M., Ouréns, R., Dione, L., Samba, I., Sánchez-Carnero, N. \& Freire, J. 2015. Lengthweight relationships for 13 fish species from a coastal artisanal fishery at Cape Verde peninsula (Senegal). J. Appl. Ichth., 31, 1177-1179. doi: 10.1111/jai.12890.

Pascual Fernández, J.J., Chinea Mederos, I., Santana Talavera, A., Martín-Sosa, P., Rodríguez Darias, A.J. \& Moreira Gregory, P.E. 2012. La pesca recreativa en Tenerife y su regulación. Santa Cruz de Tenerife: Cabildo de Tenerife.

Pasquaud, S., Pillet, M., David, V., Sautour, B. \& Elie, P. 2010. Determination of fish trophic levels in an estuarine system. Estuar. Coast. Shelf Sci., 86(2), 237-246. doi: 10.1016/j. ecss.2009.11.019.

Passley, D., Aiken, K. \& Perry, G.A. 2010. Characterization of the Jamaican Spearfishing Sector. Proceedings of the 62nd Gulf and Caribbean Fisheries Institute,62, pp. 235-240. Cumana, Venezuela: GCFI.

Pauly, D. \& Christensen, V. 2000. Trophic levels of fishes. In R. Froese,D. Pauly, FishBase 2000: Conepts, Design and Data Sources (181 pp.). Manila: ICLARM.

Pauly, D. \& Palomares, M.L. 2005. Fishing down marine food web: It is far more pervasive than we thought. Bull. Mar. Sci., 76 (2), 197-211.

Pauly, D. \& Watson, R. 2005. Background and interpretation of the 'Marine Trophic Index' as a measure of biodiversity. Philos. T. R. Soc. B, 360, 415-423. doi: 10.1098/rstb.2004.1597.

PAVlowich, T. \& Kapuscinski, A.R. 2017. Understanding spearfishing in a coral reef fishery: Fishers' opportunities, constraints, and decision-making. PLoS ONE, e0181617. doi: 10.1371/journal.pone.0181617.

Pereira, J.N., Simas, A., Rosa, A., Aranha, A., Lino, S., Constantino, E., Monteiro, V., Tariche, O. \& Menezes, G. 2012. Weight-length relationships for 27 demersal fish species caught off the Cape Verde archipelago (eastern North Atlantic). J. Appl. Ichth., 28, 156-159. doi: 10.1111/j.1439-0426.2011.01915.x.

Pita, P. \& Freire, J. 2014. The use of spearfishing competition data in fisheries management: evidence for a hidden near collapse of a coastal fish community of Galicia (NE Atlantic Ocean). Fisheries Manag. Ecol., 21 (6), 454-469. doi: 10.1111/fme.12095.

Pita, P. \& Freire, J. 2016. Assessing the impact of spear fishing by using competitions records and underwater visual censuses. Sci. Mar., 80 (1), 27-38. doi: 10.3989/scimar.04352.15A.

Pitcher, T.J. \& Hollingworth, C.E. 2002. Recreational Fisheries: Ecological Economic and Social Evaluation (Vol. Fish and Aquatic Resources Series 8). Oxford: Blackwell Science.

Reiner, F.1996. Catálogo dos peixes do arquipélago de Cabo Verde. Publ. Avuls. Inst. Port. Invest. Mar. 2, 339 p. 
RIEDE, K., 2004. Global register of migratory species -from global to regional scales. Final Report of the R\&D-Projekt 80805 081. Federal Agency for Nature Conservation, Bonn, Germany. $329 \mathrm{p}$.

Riera, R., Menci, C., Sanabria-Fernández, J.A., Becerro, M.A. 2016. Do recreational activities affect coastal biodiversity? Estuar. Coast. Shelf Sci. doi: 10.1016/j.ecss.2016.05.022.

Rocklin, D., Tomasini, J.A., Culioli, J.M., Pelletier, D. \& Mouillot, D. 2011. Spearfishing Regulation Benefits Artisanal Fisheries: The ReGS Indicator and Its Application to a Multiple-Use Mediterranean Marine Protected Area. Plos ONE, 6 (9), e23820. doi: 10.1371/ journal.pone.0023820.

Rossetti, I., Sartor, P., Belcari, P. 2003. Length-weight relationship in Sepia officinalis L. 1758, (Cephalopoda: Sepioidea) in the Eastern Ligurian Sea. Biol. Mar. Medit, 10(2), 895-899.

Santana, J.I., Lozano, I.J., Jiménez, S., Marrero, M.F., Padilla, Y., Santaella, E. \& GonzáLEZ, J.A. 2002. Campaña de pesca experimental con nasas de pescado en la isla de Fuerteventura. Proyecto financiado por la Viceconsejería de Pesca del Gobierno de Canarias.

Sazima, I. 1998. Field evidence for suspension feeding in Pseudocaranx dentex, with comments on ram filtering in other jacks (Carangidae). Environ. Biol. Fish., 53(2), 225-229. doi: 10.1023/A:1007492803796.

Sbragaglia, V., Morroni, L., Bramanti, L., Weitzmann, B., Arlinghaus, R. \& Azzurro, E. 2018. Spearfishing modulates flight initiation distance of fishes: the effects of protection, individual size, and bearing a speargun. ICES J. Mar. Sci., 75(5), 1779-1789. doi: 10.1093/icesjms/fsy059.

SCHNEIDER, W. 1990. FAO species identification sheets for fishery purposes. Field guide to the commercial marine resources of the Gulf of Guinea. Prepared and published with the support of the FAO Regional Office for Africa. FAO: Rome.

Scotт, W.B. \& Sсотт, M.G. 1988. Atlantic fishes of Canada. Can. B. Fish. Aquat. Sci., 219: 731 pp.

Sluka, R.D. \& Sullivan, K.M. 1998. The influence of spear fishing on species composition and size of groupers on patch reefs in the upper Florida Keys. Fish. Bull., 96, 388-392.

Smith, A. \& Nakaya, S. 2002. Spearfishing - Is it ecologically sustainable? 3rd World Recreational Fishing Conference Proceedings, (pp. 19-22). Northern Territory, Australia.

Sмiтн, C.L. 1997. National Audubon Society field guide to tropical marine fishes of the Caribbean, the Gulf of Mexico, Florida, the Bahamas, and Bermuda. New York: Alfred A. Knopf, Inc.

Stergiou, K.I. 2005. "Fisheries impact on trophic levels: long-term trends in Hellenic waters." In E. Papathanassiou, A. Zenetos, State of the Hellenic marine environment (pp. 326-329). Athens, Greece: Hellenic Centre for Marine Research.

Szczebak, J.T. \& Taylor, D.L. 2011. Ontogenetic Patterns In Bluefish (Pomatomussaltatrix) Feeding Ecology And The Effect On Mercury Biomagnification. Environ. Toxicol. Chem., 30(6), 1447-1458. doi: 10.1002/etc.516.

Tortonese, E. 1986. “Balistidae.” In: Whitehead, P.J.P., Bauchot, M.-L., Hureau, J.-C., Nielsen, J., Tortonese, E. (eds.)Fishes of the North-eastern Atlantic and the Mediterranean, vol. III (pp. 1335-1337). Paris: UNESCO.

Tsikliras, A.C., Torre, M.M. \& Stergiou, K.I. 2005. Feeding habits and trophic level of round sardinella (Sardinella aurita) in the northeastern Mediterranean. J. Biol. Res., 3, 67-75. 
Tuset, V.M., González, J.A., Lozano, I.J. \& García-Díaz, M.M. 2004. Age and growth of the blacktail comber Serranus atricauda (Serranidae), off the Canary Islands (Central-Eastern Atlantic). Bull. Mar. Sci., 74(1), 53-68. doi: 10.1016/j.ecss.2005.02.026.

VAldés, L. \& Déniz-González, I. (eds). 2015. Oceanographic and biological features in the Canary Current Large Marine Ecosystem. IOC-UNESCO, Paris. IOC Technical Series, No. 115: 383 pp.

Veiga, P., Machado, D., Almeida, C., Bentes, L., Monteiro, P., Oliveira, F., Ruano, M., Erzini, K. \& Gonçalves, J.M.S. 2009. Weight-length relationships for 54 species of the Arade estuary, southern Portugal. J. Appl. Ichth., 25, 493-496. doi: 10.1111/j.14390426.2009.01230.x.

Westera, M., Lavery, P. \& Hyndes, G. 2003. Differences in recreationally targeted fishes between protected and fished areas of a coral reef marite park. J. Exp. Mar. Biol. Ecol., 294, 145168. doi: 10.1016/S0022-0981(03)00268-5.

Yanes, A., Marzol, M.V. \& Romero, C. 2006. Characterization of sea storms along the coast of Tenerife, the Canary Islands. J. Coast. Res., Special Issue 48, 124-128. 


\section{TABLE}

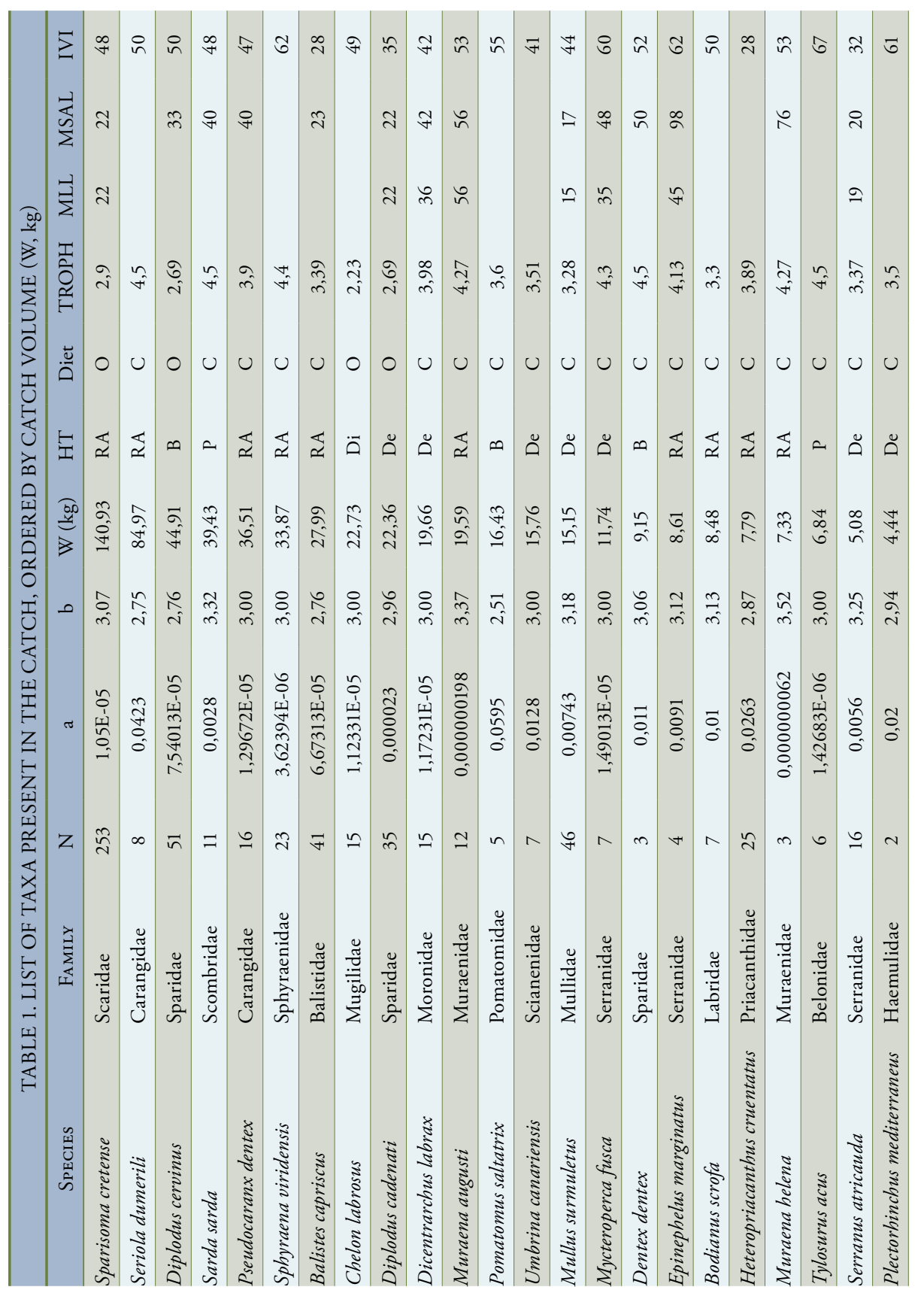




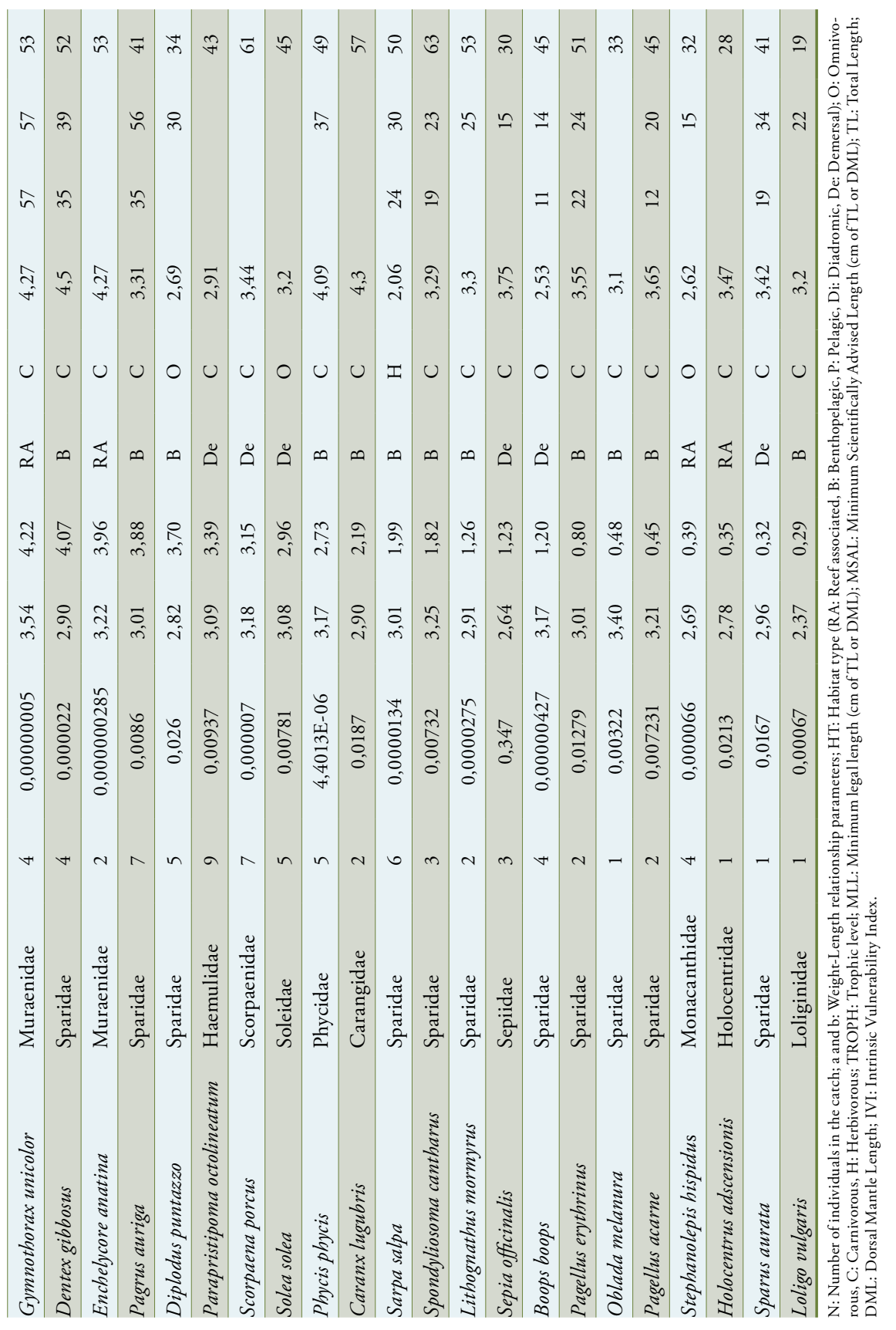




\section{FIGURES}

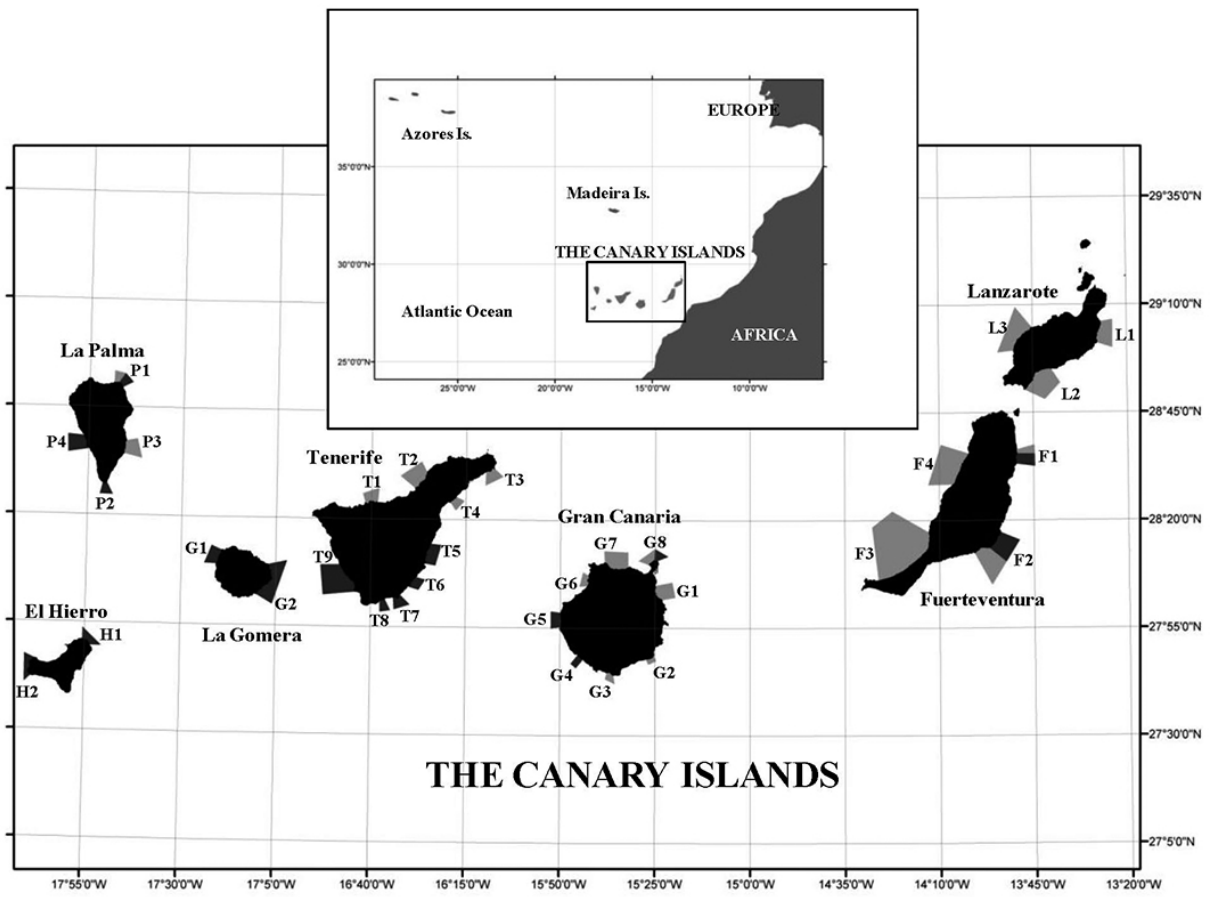

Figure 1. Map of the study area. Spearfishing open access zones for each island are light shaded when the management is Regional Government, dark shaded when is Central Government. 

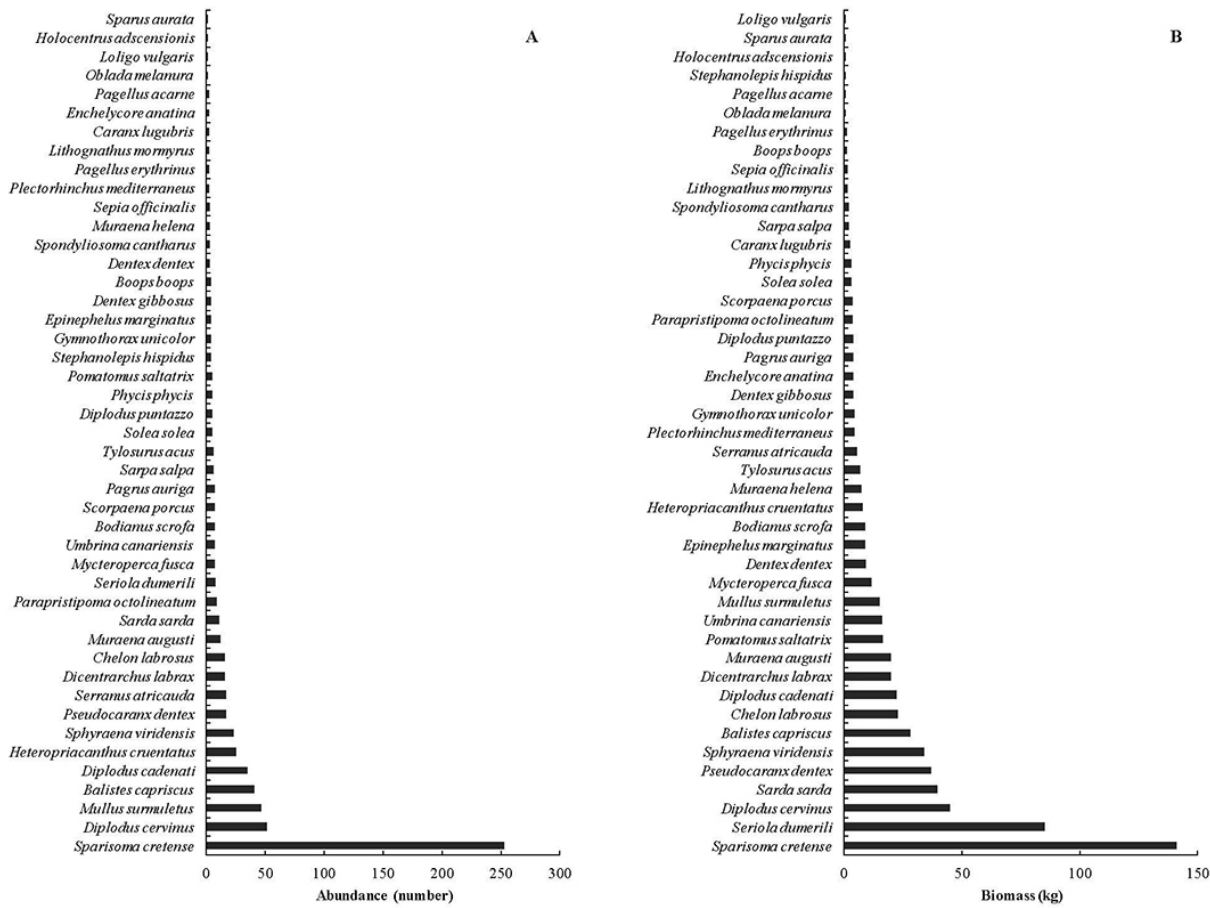

Figure 2. Species abundance (A, in number) and biomass (B, in $\mathrm{kg}$ ) in spearfishing catches. 

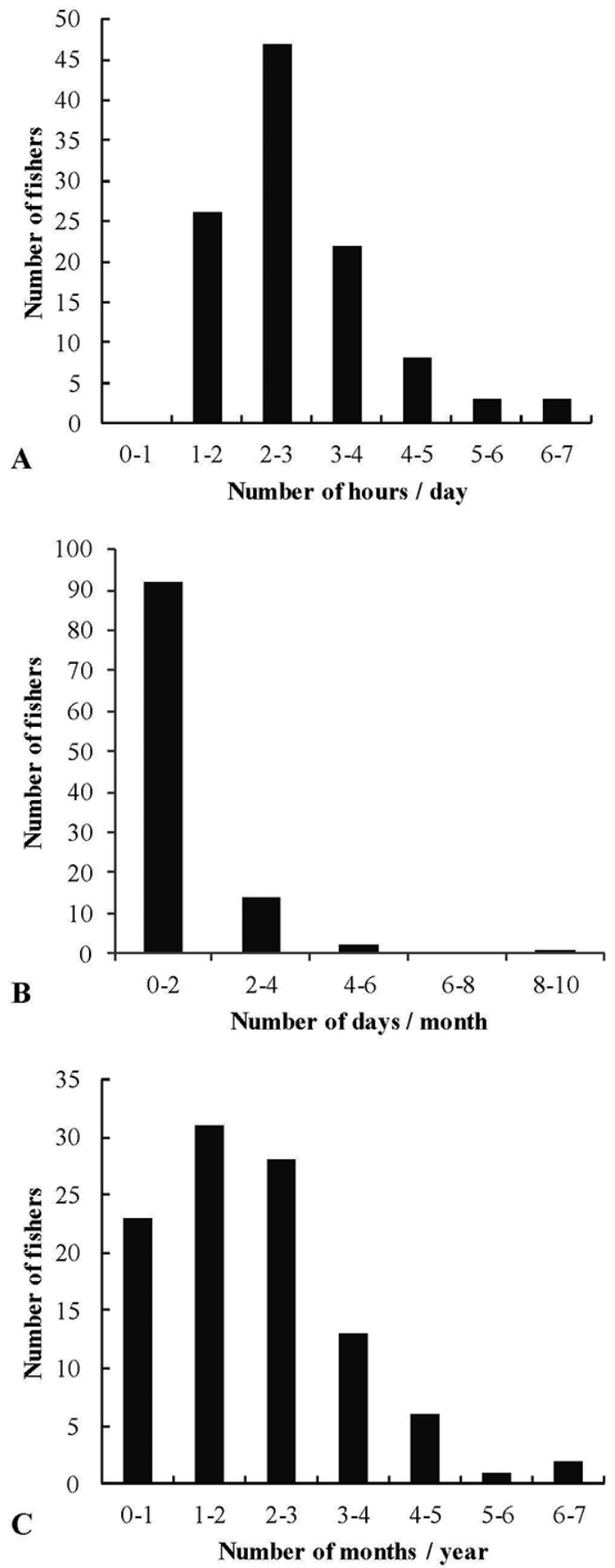

Figure 3. Reported spearfishing effort in the Canary Islands: A) Number of fishing hours per day, B) Number of fishing days per month and C) Number of fishing months per year. 


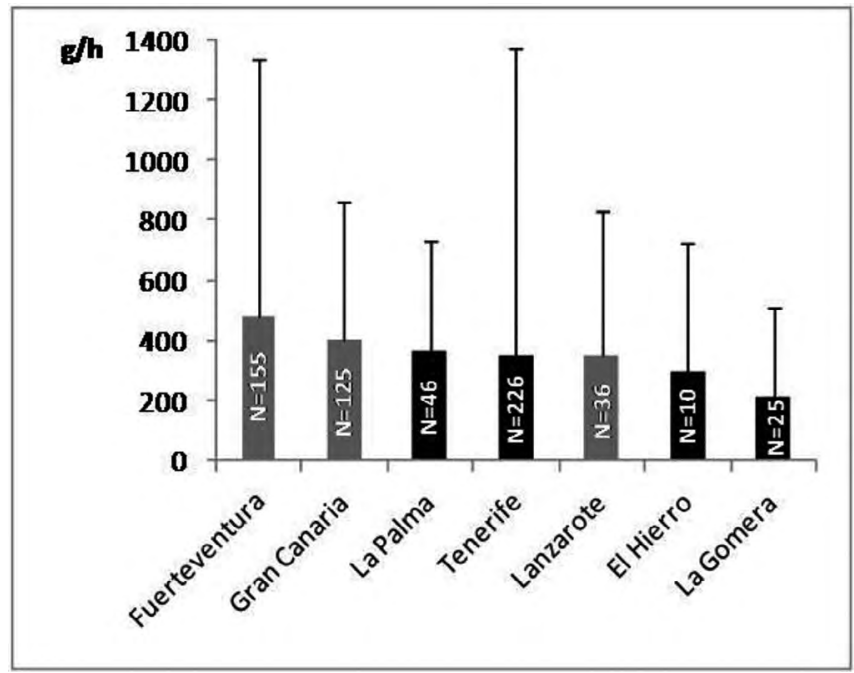

Figure 4. Mean yield $(\mathrm{g} / \mathrm{h})$ of spearfishing by island. Standard deviation is represented. $\mathrm{N}=$ number of catch reporting.

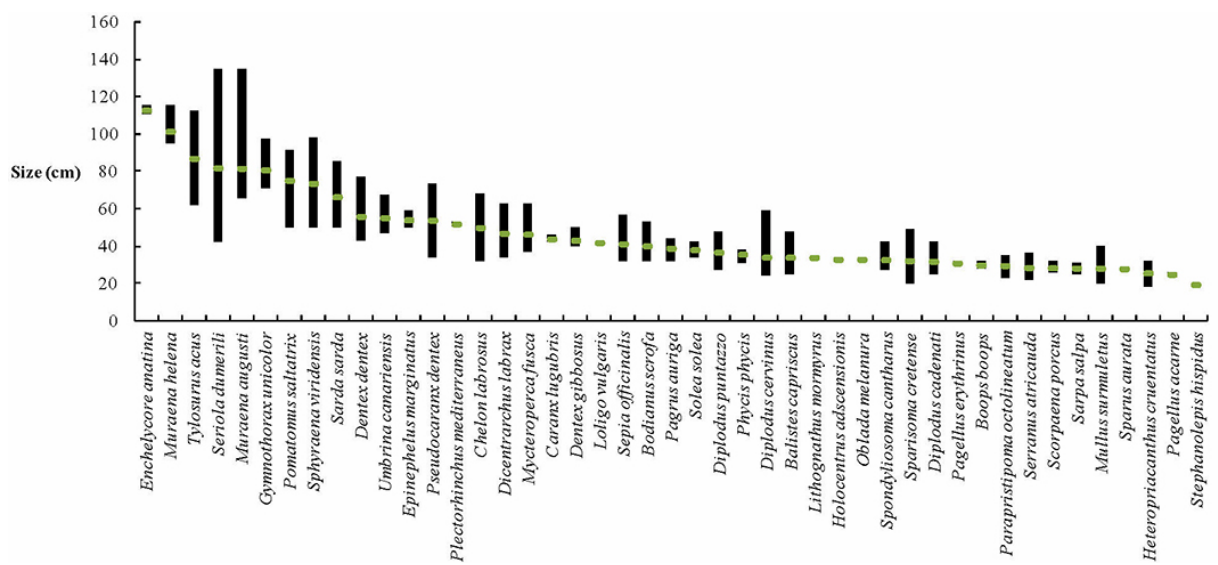

Figure 5. Mean length (marker, Total Length in $\mathrm{cm}$ for fishes, Dorsal Mantle Length in $\mathrm{cm}$ for cephalopods) of the different species in the catch. Size range is represented by the black bar. 


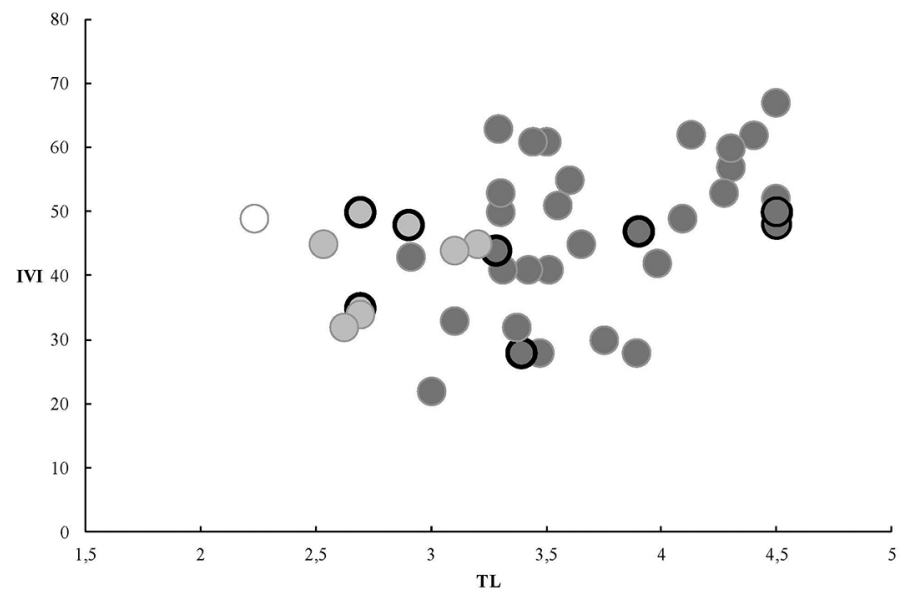

Figure 6. Intrinsic Vulnerability Index (IVI) and Trophic Level (TL) of species in the catches. Species better represented, in terms of abundance and biomass, are highlighted with black border circles. White, light grey and dark grey fillings represent herbivorous, omnivorous and carnivorous species respectively.
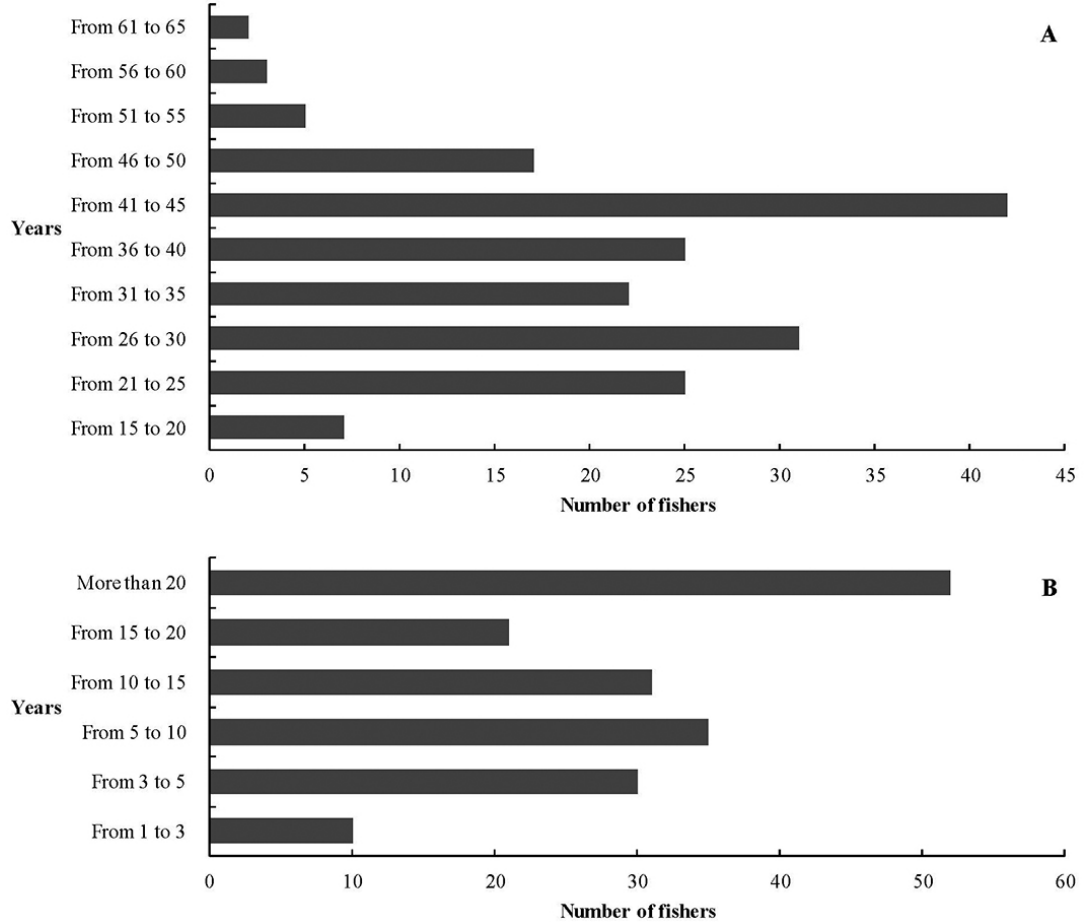

Figure 7. Number of fishers in the questionnaire by age (A, years) and by time of experience (B, years). 